Meta

Journal des traducteurs

Translators' Journal

\title{
Review of Methods Used for Coining New Terms in Arabic
}

\section{Mona Baker}

Volume 32, numéro 2, juin 1987

Vers l'an 2000. La terminotique, bilan et prospectives

Objectives: Year 2000 Terminotics. State of the Art, Prospects for the Future

URI : https://id.erudit.org/iderudit/001950ar

DOI : https://doi.org/10.7202/001950ar

Aller au sommaire du numéro

Éditeur(s)

Les Presses de l'Université de Montréal

ISSN

0026-0452 (imprimé)

1492-1421 (numérique)

Découvrir la revue

Citer cet article

Baker, M. (1987). Review of Methods Used for Coining New Terms in Arabic. Meta, 32(2), 186-188. https://doi.org/10.7202/001950ar d'utilisation que vous pouvez consulter en ligne.

https://apropos.erudit.org/fr/usagers/politique-dutilisation/ 


\title{
REVIEW OF METHODS USED FOR COINING NEW TERMS IN ARABIC
}

\author{
MONA BAKER
}

Kidderminster, U.K.

For several decades, language academies in the Arab World have attempted to standardize terminology by setting strict rules for the creation of new terms and by publishing glossaries of recommended specialized vocabulary ${ }^{1}$. The terms and rules put forward by the academies have not always been adopted or adhered to and often have the adverse effect of creating more synonyms rather than standardizing a specific term. The final decision as to which terms are accepted and assmilated into the language is generally made by translators, writers and, eventually, Arab readers.

A number of options are available for coining new terms in Arabic; not all are sanctioned by the academies. The main methods are as follows :

\section{AL-ISHTIQAQ (DERIVATION)}

In theory, the structure of the Arabic language offers unlimited potential for the derivation of new terms by analogy. Arabic is based on a system of three radical consonant roots ${ }^{2}$. Any given root carries a specific meaning and is used to generate various verbal and nominal forms by the addition of prefixes, suffixes and vowels in certain positions, according to set patterns. The resulting patterns are also associated with certain meanings. Apart from using the natural resources of the language, the advantage of this method is that it provides the reader with easy access to the meaning of the word through the inherent meaning of its root and pattern. For example, the pattern $\mathrm{MaC}$ $\mathrm{CaC}$ generally indicates a "noun of place", and the pattern $\mathrm{CiC} \bar{a} \mathrm{Ca}$ indicates a craft or profession. it is therefore easy to guess the meaning of a word like "masna ?" [factory from "sn?", to manufacture]; "siba $a k a$ " [founding/casting trade - from " $s b k$ ", to found or cast] ; "marsam" [studio, of an artist - from "rsm", to paint] ; "tiba ?a" [printing from " $t b$ ?", to print], etc. Because this method provides a powerful tool for coining new terms in Arabic, it is favoured by the academies as the most natural way of enriching the language without altering its identity. Arabic is often referred to as "Lughat al-ishtiquāq" (language of derivation). Examples of new terms coined by derivation are : "mu?tayāt" (data)

"jih äz" (apparatus)

"muwallid" (generator)

from "?tw" (to give or present)

from " $j h z^{\prime \prime}$ (to prepare or equip)

from "wld" (to beget or generate)

\section{AL-ISTINBAĀT (DISCOVERY)}

This method consists of reviving old archaisms and extending their meanings to express new concepts. It is one of the methods favoured by the academies since it utilizes the rich lexicon of Arabic instead of introducing new elements to it. In their attempt to promote this method, the academies have not always been successful. Some of the archaisms they sought to revive have been the subject of much ridicule. These include words like "irziz" (suggested for telephone; originally meaning sound of rain), "tirbăl" (suggested for skyscraper; originally meaning high building), and "jammāz" (suggested for tram; originally meaning swift-footed camel). Revived archaisms which 
have gained acceptance include "qitär" (train ; originally used to describe a train of camels) and "bïäh" (environment ; originally meaning place of abode).

\section{AL-ISHTIQAĀQ BI AL-TARJAMAH (LOAN TRANSLATION/CALQUES)}

This involves the actual translation of the meaning of a foreign term into Arabic. Terms created by this method have generally gained acceptance and include the following :

"?ilmul 'aswāt"

"mu ?ālajat al-kalimāt"

"Al-tahlïl al-nafsĭ"

"Fāida murakkaba"
- (Phonetics ; literally "science of sounds)

- (Word processing)

- (Psychanalysis)

- (Compound interest)

\section{4. $A L-T A$ ?RIB (ARABIZATION)}

Arabization involves the rendering of a foreign term into Arabic in its original linguistic form, after introducing minor phonetic and morphological changes where necessary. This method has received much opposition from language purists, who fear that the assimilation of foreign terms may change the identity of Arabic and, if applied to excess, would even result in some form of a hybrid language. However, faced with the massive influx of new terms which need to be rendered into Arabic, even the purists have had to accept Arabized terms which have found their way into the language and increasingly gained acceptance, with or without the academies' approuval.

It is worth noting that derivation from Arabized terms is generally restricted since they cannot be made to fit into the Arabic root and pattern system. The Arabized term "al-komputer" (computer), for instance, has generated no patterns to accommodate words like computerize, computerized, compute or computing; these terms cannot be transferred as single items into Arabic but have to be translated by a phrase. In spite of this restriction and the disapproval of the academies, Arabization remains one of the most common methods of introducing new vocabulary into Arabic. Examples of established Arabized terms are numerous and include : "kataloj" (catalogue); "klatsh" (clutch) ; "ilaktron" (electron) ; "al-bit" (bit - binary digit) ; "vidio" (video) ; "radahār" (radar); "tiliscóp" (telescope), etc. The Arabized term "tilifizyōn" (television) is unusual in that it has generated several others patterns such as "talfaza" (to televise), "mutalfaz" (televised) and "tilifizyoni" (nisba adjective, as in "television broadcast").

Due to the largely unco-ordinated and generally inconsistent work of language academies, translators, writers, research and educational institutes in the Arab World, as well as regional variations of Arabic, modern Arabic suffers from two major problems. On the one hand, there is a serious lack of terms describing the ever increasing influx of new concepts and innovations from the West, which results in a sense of frustration among Arab writers and translators due to not being able to call the new things by their names. The issue is often not choosing the appropriate term sanctioned by the academies or by usage but finding any term to describe some of the new concepts. At the same time, there is an over-abundance of synonyms for many specialized terms; some Arabized, others derived from Arabic roots or appropriate for certain registers only and others only used in certain countries (such as "fressione" for "clutch", used in Libya). Bilingual Arabic dictionaries generally give no indication of how to use the various synonyms ; they simply list them.

Having acknowledged that terminology poses a serious problem for the Arab translator or writer, it would be naive to assume that providing the correct term for every new concept or innovation will result in smooth translations and consequent comprehension by the reader. Many specialized and high technology Arabic texts, such as computer or word processing literature, read like reports on totally archaic subjects and 
are often inaccessible to an Arab reader. The difficulty does not simply arise from the terms used - these are often sanctioned by the academies or coined according to the accepted method of derivation. Not only that, but new terms often appear in Arabic texts accompanied by the foreign term in brackets or with a footnote explaining their meanings (a convention which enables the reader to understand the individual terms but creates distraction and obstructs the natural flow of argument). The problems, however, is that understanding the individual terms does not ensure comprehension of the text as a whole. One of the major factors contributing to this phenomenon could well be that translation activity in the Arab World is still too slow when compared to the speed with which new terms are coined for new concepts in the West and the frequency of their usage once coined. Specialized and high technology literature is translated into Arabic on a relatively small scale, with the result that the individual frequency of most newly coined terms across Arabic texts is very low, while the total frequency and number of new terms in a given text may be too high to allow comprehension of the text as a unit.

To sum up, although terminology is a serious problem for Arab translators and writers and contributes to the slow pace of translation activity in the Arab World, many newly coined Arabic terms cannot become well established or standardized without a considerable increase in translating specialized texts into Arabic.

Notes

1. For further details on language academies and terminological activities in the Arab World, see M.E. Sieny (1985) : "Scientific Terminology in the Arab World : Production, Co-ordination and Dissemination", in META, 30:2, June. See also W. Nedobity (1984) : "Terminological Activities in the Arab World", Infoterm, 9.

2. A few roots consist of two and others of four radicals.

\section{BIBLIOGRAPHY}

AL-KHATIB, A. (1982) : A New Dictionary of Scientific and Technical Terms, English-Arabic, Librairie du Liban.

AZIZ, Y. (1982) : "Cultural Problems of English-Arabic Translation", in Babel, no 1.

EL-SAYED, D. (1983) : "Notes on the Arabization of the Terminology of Modern Linguistics", in LEXICOGRAPHICA Series Maior 1, LEXeter' 83 Proceedings, Nicmeyer.

EMERY, P. (1983) : "Towards the Creation of a Unified Scientific Terminology in Arabic", in B. Snell (ed.), Term Banks for Tomorrow's World, Aslib.

NEDOBITY, W. (1984) : "Terminological Activities in the Arab World", in Special Language/Fachsprache, 6, no 1-2 (Infoterm, Sept.)

SIENY, M. (1985) : "Scientific Terminology in the Arab World : Production, Co-ordination, and Dissemination", in META, 30-2, June.

STETKEVYCH, J. (1970) : The Modern Arabic Literary Language, The University of Chicago Press.

WEHR, H. (1961) : A Dictionary of Modern Written Arabic, Cornell University Press. 